\title{
Influence of some Organic Manure and NPK 15:15:15 on Selected Physical Properties of Sandy Loam Soil in Mokwa Niger State Nigeria
}

\author{
Mohammed JIYA MAMMAN ${ }^{1}$ \\ ${ }^{1}$ Department of Crop Production Technology, Niger State College of Agriculture, Mokwa, Nigeria \\ Correspondence: Mohammed JIYA MAMMAN, Department of Crop Production Technology, Niger State College \\ of Agriculture, Mokwa, Nigeria. E-mail: ikwan1565@gmail.com
}

Received: February 17, 2020 Accepted: February 28, 2020 Online Published: March 11, 2020

\begin{abstract}
The result of long time farming and poor soil management and conservation practices at Niger state college of Agriculture Mokwa Commercial farm which is the study area has led to serious soil degradation like nutrient depletion and soil erosion. There is the need for local content research and innovation to ameliorate the problem. This research work described the effect of organic manure and inorganic fertilizer (poultry manure, Cow dung and NPK fertilizer) on some soil physical properties i.e. the infiltration, porosity, bulk density and erodibility on a sandy loam soil of Mokwa North Central Nigeria. Four treatments of poultry, cow dung manure, NPK 15:15:15 fertilizer and non - application were applied in RCBD with 25t/ha of poultry manure and cow dung while NPK $15: 15: 15$ was $150 \mathrm{~kg} / \mathrm{ha}$ and non- application as control replicated three times. Soil physical properties were measured and analyses were done to ascertain the soil aggregates. Ring infiltrometers were constructed and used to test the infiltration rate of the soil at each plot before soil treatments. Measurements were taken at time intervals for all the plots. The plots were then treated with manure and NPK and left for two weeks to decompose, after which infiltration measurements were taken again. Minitab 17 and Excel were used for the analysis. The cow Dung manure shows highest infiltration rate as compared to other treatments. The experiment shows that Cow Dung and poultry manure can be used to correct infiltration and soil physical anomalies especially when soil is compacted or clayey.
\end{abstract}

Keywords: infiltration rate, soil physical properties, organic manure, bulk density, porosity

\section{Introduction}

The upper most part of the soil layer is the most fertile part in soil structure which contains the most organic, nutrient-rich materials. It is however threatened by soil erosion. Soil erosion is therefore a grave environmental, economic, and social problem, which does not only causes severe land degradation and soil productivity loss, but also threatens the stability and health of society in general and sustainable development of rural areas in particular (Lal, 1991; Tang, 2004; Zheng et al., 2004; Jing et al., 2005). The factors affecting soil erosion can be classified into the amount and intensity of rainfall and wind velocity, topography with special reference to slope of land, physical and chemical properties of soil and ground cover, its nature and extent.

Soil erodibility refers to the resistance of soil to detachment and transport of particles and aggregates. Erodibility is a function of soil texture, aggregate stability, shear strength, infiltration capacity, organic, and chemical contents (Morgan, 2001). It is a resistance to two energy sources: the impact of raindrops on the soil surface, and the shearing action of runoff between clods in grooves or rills. In recent year, many authors including Evrendilek et $a l$,. (2004) and Khormali et al. (2009) have used the USLE-K factor as an indicator of soil erosion, because it is a measure of soil susceptibility to erosion. The soil under native grass and conventional tillage would behave differently in terms of aggregate size distribution, aggregate stability and erosion.

Soil physical properties are important for favourable conditions for crop growth and maintaining soil quality. Many practices are known to influence soil physical properties. These include crop type (Alberts and Wendt, 1985), cultivation (Gantzer and Blake, 1978) and application of organic residues (Anderson et al., 1990; Gantzer et al., 1987; Ekwue, 1990; Gajic et al., 2006; Gülser and Candemir, 2012; Cercioğlu, et al., 2014). Soil degradation involves destruction of soil structure due to loss of organic matter by intensive agriculture practices (Gülser and Candemir, 2006). Most studies showed that amelioration of soil physical properties largely based on increases of organic carbon in the soils with using organic wastes. Effects of application of organic residues on soil physical properties are often related to increases in soil organic matter (Özdemir, 1993; Haynes, 2000). Soil organic matter 
is an essential but transient component of the soil that controls many physical, chemical and biological properties of the soil (Carter, 1996). The stability of soil aggregates often decreases for soil under annual crops, such as wheat or corn (Angers, et al., 1999). Gantzer, et al. (1987), reported that residue quantity had a larger effect on splash detachment, shear strength and aggregate stability than residue type. MacRay and Mehuys (1985), concluded that long-term pastures were ideal for improving soil aggregation.

Infiltration is the entry of water into the soil. The rate of infiltration determines the amount of water, which will enter the soil and the amount of water, which will run on soil surface as runoff (Hillel, 1982). Therefore, the water infiltration rate can be considered as an important soil property which significantly influences the amount of surface runoff and hence, the degree of soil erosion Since most areas of land are used for agricultural production, a small loss in the infiltration capacity of agricultural soils may produce serious impacts on flood intensity. For instance, water infiltration rates less than $15 \mathrm{~mm} / \mathrm{h}$ were found to be related to increased flood intensity (Sparovek, et al., 2002). Therefore, sustaining enhanced water infiltration ability into the soil of agricultural areas is considered as a precautionary way for protection against river floods. It can be concluded that water infiltration is actually one of the preservative means of soils, especially against erosion induced by surface runoff. The rate of infiltration is affected by different chemical, biological and physical soil properties, like organic matter content, biological activity, earthworms, soil sealing and crusting, and compaction. Agricultural management practices like tillage, fertilization and crop rotation also affect the infiltration of water into the soil (Rogasik, et al., 2004).

Many soil properties, including physical, chemical, biological, and mineralogical properties affect soil erodibility; it is linked to the combined actions of rainfall, runoff and infiltration on soil. The unavailability of adequate information on the erodibility of the study area soils and the widespread erosion problem in the country has necessitated this study to be carried out. It is intended to determine the most important physical and chemical properties that affect the erodibility of soils from some the study area and its effect on yield of maize. The aim of the study is to evaluate the Effect of organic manure sources and inorganic fertilizer on soil physical properties improvement for agricultural purposes.

\section{Materials and Method}

\subsection{Materials}

The materials to be used are double ring infiltrometers, core samplers, ruler, measuring tape, oven, nylon bags and shovel or trowel

\subsection{Study Area}

The study area is Niger State College of Agriculture Mokwa, Mokwa is a Local Government Area in Niger State, Nigeria. It is located at an elevation of 88 meters above sea level. Its coordinates are $9^{\circ} 16^{\prime} 60^{\prime \prime} \mathrm{N}$ and $5^{\circ} 3$ '0" $\mathrm{E}$ in DMS (Degrees Minutes Seconds) or 9.28333 and 5.05 (in decimal degrees) (Figure 3.1).

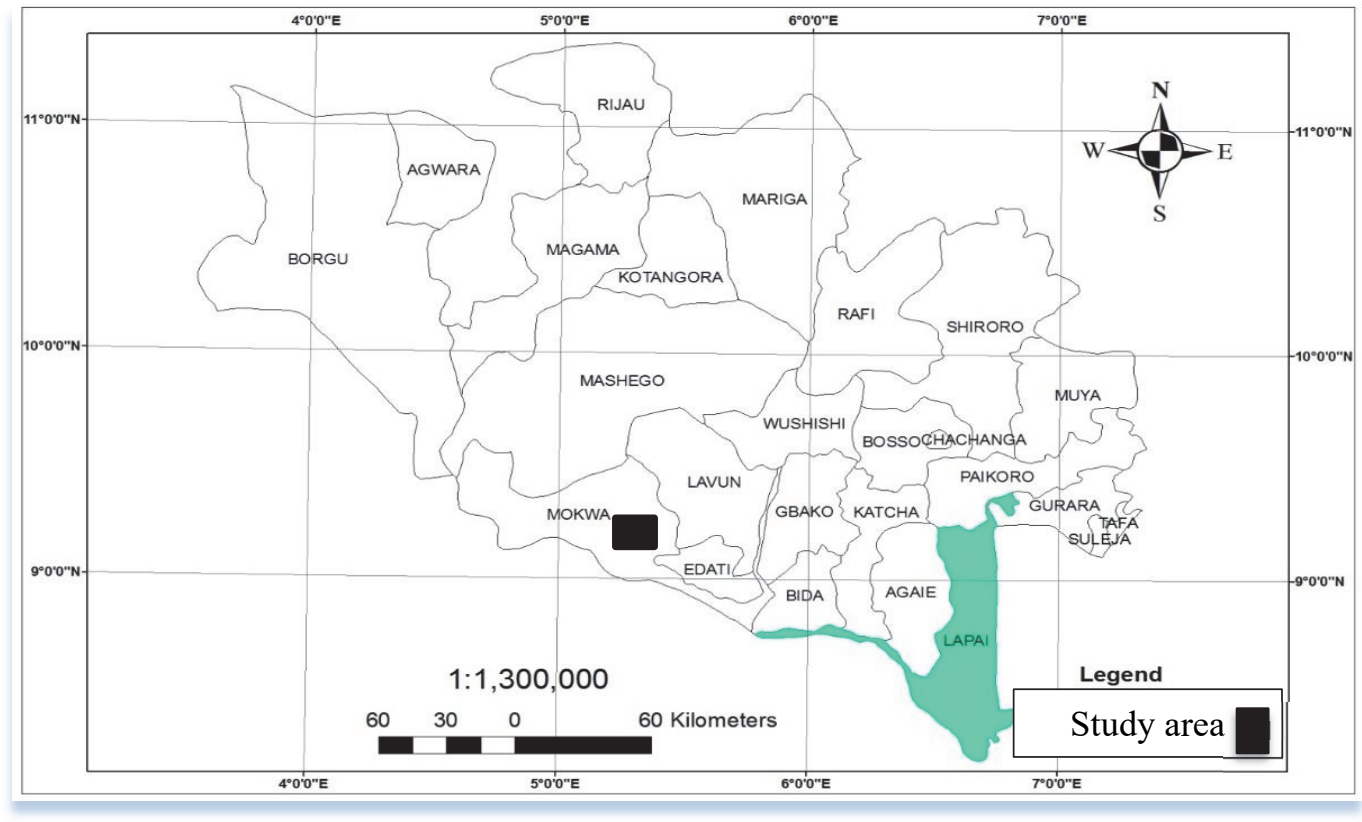

Figure 1.1. Map of Mokwa 


\subsubsection{Climate and agro-ecology}

Mokwa local Government experiences two distinct seasons, the dry and wet seasons. The annual rainfall varies from about $1000 \mathrm{~mm}$ in the south to $1,200 \mathrm{~mm}$. The duration of the rainy season ranges from 150 to 210 days. Mean maximum temperature remains high throughout the year, hovering about $32{ }^{\circ} \mathrm{F}$, particularly in March and June. However, the lowest minimum temperatures $\left(21-23^{\circ} \mathrm{C}\right)$ occur usually between December and January when most parts of the state come under the influence of the tropical continental air mass which blows from the north. Dry season commences in October.

\subsubsection{Topography and Soil}

The study area has a flat to low land terrain with more than half the total area rising to an average height of about 88 meters above sea level. The land is relatively flat. The soils aremostly sandy loam, having relatively high silt contents. This may be due to the nature of the parent material which is sedimentary rock (Adepoju, 1993).

\subsubsection{Geology}

The soils of Mokwa are derived from basement complex rocks and Nupe sand stone respectively. They ranged from shallow to very deep soils overlying deeply weathered gneiss, granites, quartzites, schist and magmatites which gave rise to a wide variety of soil (Bennett, et al., 1979). Some are underlain by iron pan at varying depth. Alhassan, et al., (2012) observed quartz to be prominent mineral constituents of the soils around the study locations

\section{Methods}

\subsection{Soil Sampling, Cultural Practices and Experimental Design}

Arable field was selected from Niger state college of agriculture farm. The field was cleared with minimum disturbance; four plots of $3 \mathrm{~m} \times 3 \mathrm{~m}$ were made on the field with $1 \mathrm{~m}$ pathway. The plots were set up in randomized complete block design (RCBD). Infiltration tests were carried out on the undisturbed soil plots of each plot and replicated 3 times. Two soil samples were taken from each plot at depths of $0-30 \mathrm{~cm}$ with soil core sampler/augers to determine soil physical.

After the physical analysis of the undisturbed soil samples, the soil were later subjected to four treatments of $25 \mathrm{t} / \mathrm{h}$ cow manure, $25 \mathrm{t} / \mathrm{h}$ poultry manure, $150 \mathrm{~kg} / \mathrm{ha}$ NPK 15:15:15 fertilizer by broadcasting and the control without application. The plots were subjected to infiltration tests after two weeks. This was to determine the effect of the treatments soil physical properties.

\subsection{The Particle Size Distribution}

The particle size distribution was carried out using the hydrometer method (Agbede and Ojeniyi, 2005).

\subsection{Soil Particle Density}

The soil particle density was determined using laboratory procedure and applying the relationship as:

$$
\text { Particle density }=\frac{\text { mass of dry soil }}{\text { volume of soil particle only (air removed })}\left(\frac{\mathrm{g}}{\mathrm{m}^{3}}\right)
$$

\subsection{The Bulk Density}

The bulk density of the soil was determined using intact core samplers to collect a known volume of soil (the volume of the core sampler) and by determining the weight of the soil after drying (Hunt and Gilkes, 1992; McKenzie et al., 2004). The bulk density was calculated as the oven dry mass of the soil divided by the core volume.

$$
\text { Bulk density }\left(\mathrm{g} / \mathrm{cm}^{3}\right)=\text { Dry soil weight }(\mathrm{g}) / \text { Soil volume }\left(\mathrm{cm}^{3}\right)
$$

\subsection{Soil Erodibility}

Soil erodibility values were obtained using Wischmeier and Smith model (Wang et al., 2013)

$$
k=\frac{2.1 \times 10^{-4}(12-O M) M^{1.14}+3.25(S-2)+2.5(P-3)}{100}
$$

Where;

$\mathrm{k}=$ USLE (Universal Soil Loss Equation) soil erodibility factor

$\mathrm{M}=(\%$ silt $+\%$ very fine sand $)(100-\%$ clay $)$

$\mathrm{OM}=$ Soil organic matter content $(\%)$ 
$\mathrm{S}=$ Soil structural code

$\mathrm{P}=$ Soil permeability code

The structural codes and permeability codes obtained as described by Wischmeier and Smith (1978) and Fasinmirin and Olorunfemi (2014).

\subsection{The Water Content and Porosity}

The water content and porosity of the soil at selected layer of 0 - 30 were determined by oven-drying method at temperature $105^{\circ} \mathrm{C}$ for 24 hours. The water content was calculated as the ratio of weight of water to the dry weight of solid particle and the porosity was determined as stated by Fasinminrin and Adesigbin (2012).

$$
\text { Porosity }=1-(\text { bulk density/particle density) }
$$

\subsection{The Infiltration Test}

The infiltration test was carried out on the field using double ring infiltrometer. The inner and outer rings were 30 and $60 \mathrm{~cm}$ in diameter, respectively. Both collars were $27 \mathrm{~cm}$ height and inserted to a depth of $5 \mathrm{~cm}$ in the soil. The surface and vegetation were left intact while installing the ring. Some gravel was poured inside the rings to avoid soil disturbance and a constant head of $25.6 \mathrm{~cm}$ of water was maintained in both the inner and the outer rings. The infiltration rate $\left(\mathrm{cmh}^{-1}\right)$ was computed following the method described in Gregory et al. (2005).

$$
\text { Infiltration rate }=k+\frac{1}{2} s \times t^{0.5}
$$

$\mathrm{K}=$ the final infiltration rate $(\mathrm{cm} / \mathrm{hr})$

$\mathrm{s}=$ the soil coefficient related to the initial water content $(\mathrm{cm})$

$\mathrm{t}=$ the time from the beginning of infiltration $(\mathrm{h})$

\subsection{Data Analysis}

The data obtained were analysed using descriptive statistics, regression analysis and Analysis of Variance.

\section{Results and Discussion}

Table 2.1. Soil Physical Properties

\begin{tabular}{lllllll}
\hline S/N & Soil properties & $\begin{array}{l}\text { Non application } \\
\text { of any Treatment } \\
\text { (Control T4na) }\end{array}$ & $\begin{array}{l}\text { Soil } \\
\text { with } \\
\text { Manure (T1ptr) } \\
\text { Poultry }\end{array}$ & $\begin{array}{l}\text { Soil Treated } \\
\text { with } \\
15: 15: 15 \\
(\mathrm{~T} 2 \mathrm{flz})\end{array}$ & $\begin{array}{l}\text { Soil Treated } \\
\text { with }\end{array}$ & $\begin{array}{l}\text { Dung } \\
\text { (T3cwd) }\end{array}$ \\
\hline 1 & Sand (\%) & 65 & 65 & 65 & 65 \\
2 & Silt (\%) & 27 & 28.1 & 27.2 & 27.6 \\
3 & Clay (\%) & 34 & 34.2 & 34.0 & 34.4 \\
4 & Bulk density $\left(\mathrm{g} / \mathrm{cm}^{3}\right)$ & 1.66 & 1.46 & 1.58 & 1.54 \\
\hline 5 & Moisture content $(\%)$ & 10.55 & 10.55 & 10.55 & 10.55 \\
\hline
\end{tabular}

The results from the soil physical properties analysis in table 1 shows that the soil is sandy loam with sand being $65 \%$ and clay as $34 \%$ from the soil textural class triangle. The bulk average density was $1.36 \mathrm{~g} / \mathrm{cm} 3$ and the moiture content at the time of the initial and final infiltration test was approximately $10.55 \%$. This shows low moisture content of the soil at the time of conducting soil infiltration test and bulk density. The soil physical test shows high percentage of sand, clay and silt.

\subsection{Soil Bulk, Particle Density, Porosity and Erodibility Factors as Affected by the Treatments}

Soil bulk density is the mass of dry soil per unit of bulk volume, including the air space. Soil bulk density can vary substantially among different soil types and is affected by management practices (e.g. tillage, livestock grazing, timber harvesting). Particle density is the volumetric mass of the solid soil. It differs from bulk density because the volume used does not include pore spaces. Particle density represents the average density of all the minerals composing the soil. Porosity is that portion of the soil volume occupied by pore spaces. Erodibility factor K measures the vulnerability or easiness of a soil to be removed by erosion agents. 
Table 2.2. Soil Physical Properties as Affected by the Treatments

\begin{tabular}{|c|c|c|c|c|c|}
\hline Treatment & Bulk density $\mathrm{g} / \mathrm{cm}^{3}$ & $\begin{array}{l}\text { Particle } \\
\mathrm{g} / \mathrm{cm}^{3}\end{array}$ & Density & Porosity (\%) & Erodibility Factor K \\
\hline $\begin{array}{l}25 \text { tha poultry } \\
\text { Manure (T1ptr) }\end{array}$ & $1.46333 \mathrm{~d}$ & $2.6567 \mathrm{a}$ & & $45.267 \mathrm{a}$ & $0.002733 \mathrm{c}$ \\
\hline $\begin{array}{l}\text { NPK15:15:15 } \\
\text { 150K-ha (T2ftlz) }\end{array}$ & $1.58333 b$ & $2.6733 \mathrm{a}$ & & $41.400 \mathrm{~b}$ & $0.06567 \mathrm{~b}$ \\
\hline $\begin{array}{l}\text { 25tha cow dung } \\
\text { (T3cwd) }\end{array}$ & $1.55000 \mathrm{c}$ & $2.6233 \mathrm{a}$ & & $41.600 \mathrm{~b}$ & $0.5997 \mathrm{a}$ \\
\hline Control (T4na) & $1.6700 \mathrm{a}$ & $2.6467 \mathrm{a}$ & & $38.167 \mathrm{c}$ & $0.0563 \mathrm{bc}$ \\
\hline
\end{tabular}

Same letter within each column indicate no significant differences among the treatments $(\mathrm{P} \leq 0.05)$.

The table 2.2 shows the means of bulk density, particle density, and Porosity and Erodibility factor. For the bulk density, there was significant difference between the all the treatments. There were reduction in the bulk density with poultry manure application having the lowest and NPK 15:15:15 having the highest. Figure 2.1 shows the standard deviation bars of bulk density with cow dung and non-application having higher values. There was no significant difference among the treatments for the particle density and the P-value of 0.17 shows that the null hypothesis is true.
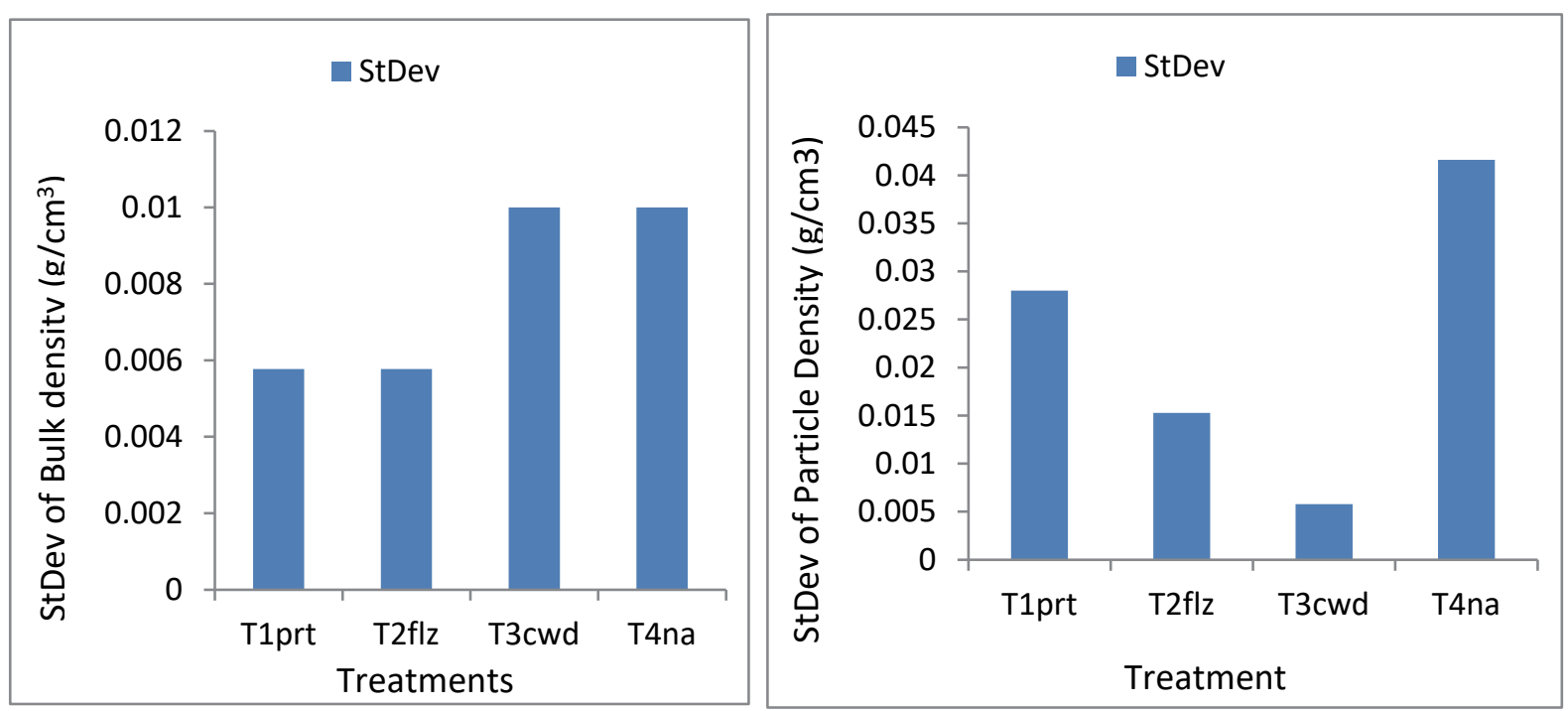

Figure 2.1. Standard Deviation Bars for Bulk and particle density as affected by Treatments 

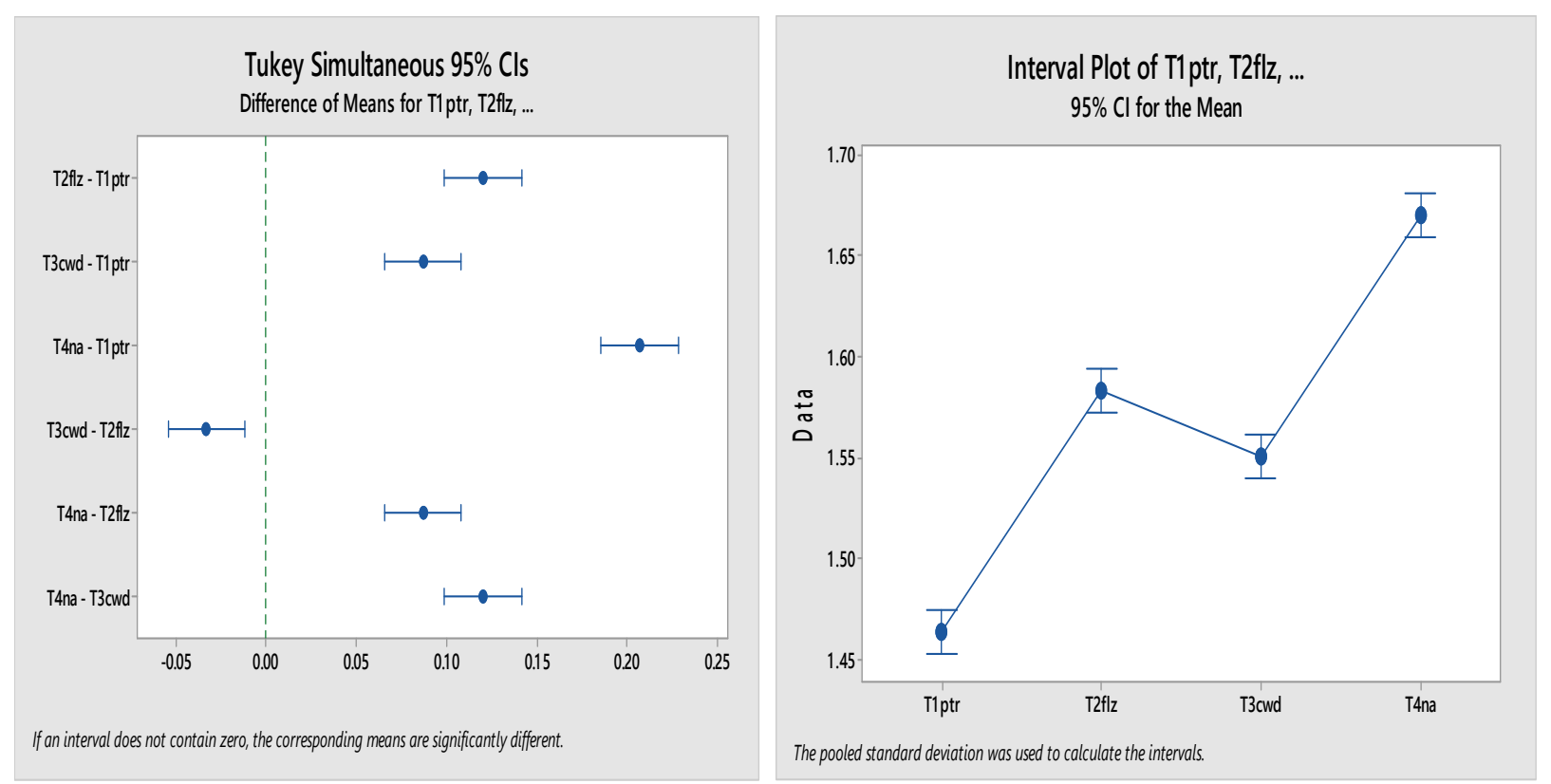

Figure 2.2. Confidence level (a) and interval Plots (b) of bulk Density as Affected by Treatments

From figure 2.2 (a) if an interval does not contain zero, the corresponding means are significantly different and $\mathrm{b}$ shows the interval plots pooled from standard deviations. The P- Value of 0.00 calculated from the ANOVA shows that there is significant difference among the treatments for bulk density.

\subsubsection{Soil Porosity}

Porosity defines the amount of void spaces in the soil; it defines how porous a medium is. Figure 2.3 compares porosity and bulk density of the soil as it affected by soil treatments. Soil treated with poultry droppings, cow dung, and NPK15:15:15 are represented as T1ptr, T2flz, T3cwd and T4na respectively. The soil treated with nonapplication has porosity of 38.1 percent; with cow dung (TT3cwd) was 41 percent, with NPK 15:15:15 (T2flz) was 41 percent and poultry (Tr1ptr) was 45 percent. The R2 value of 0.89 obtained show significant trend among the soil treatment applied. It shows the organic manure application can have significant effect on the soil physical structure and properties as porosity.

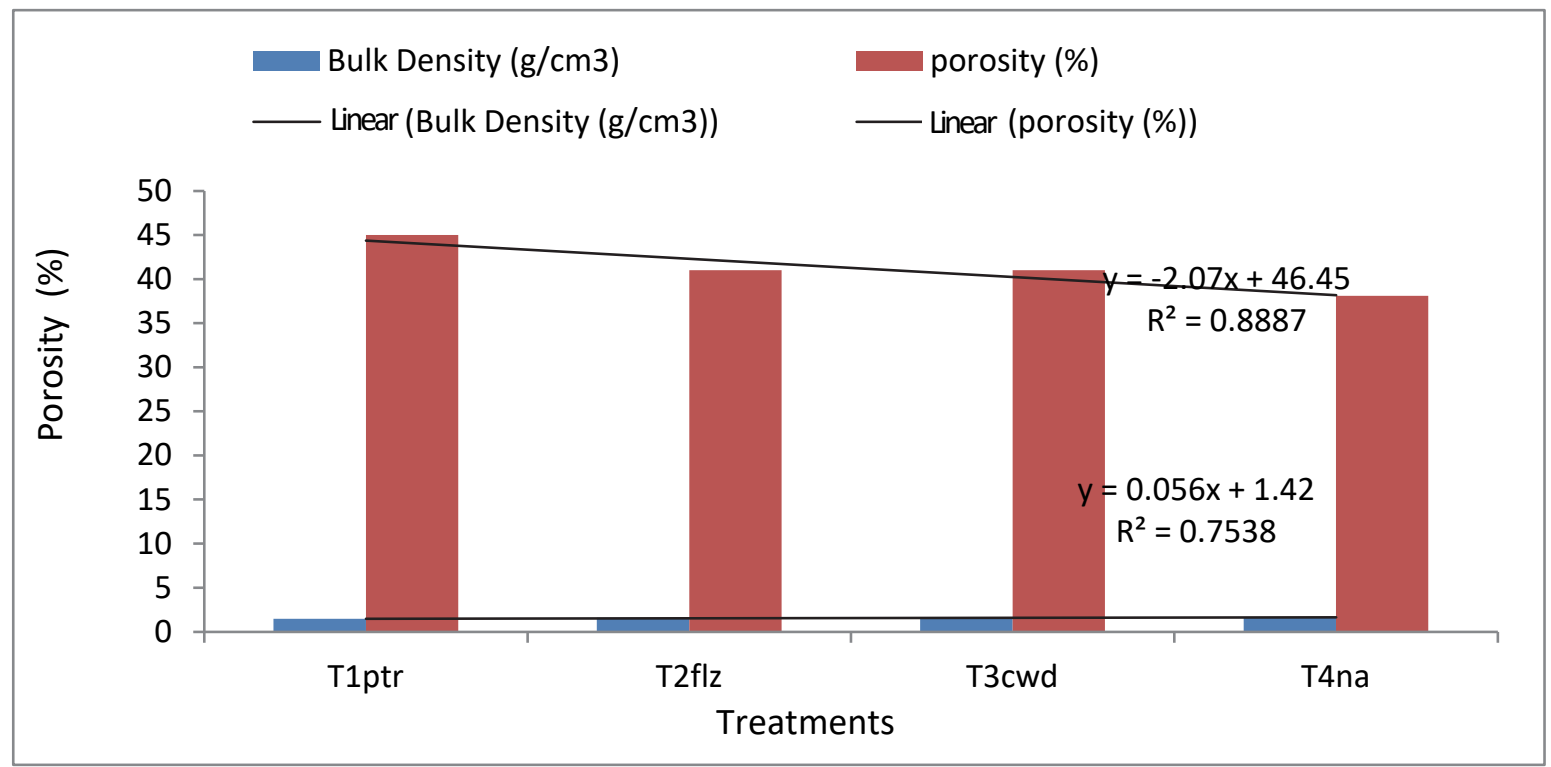

Figure 2.3. The Soil Bulk Density of the Soil as it Affected by the Treatments 

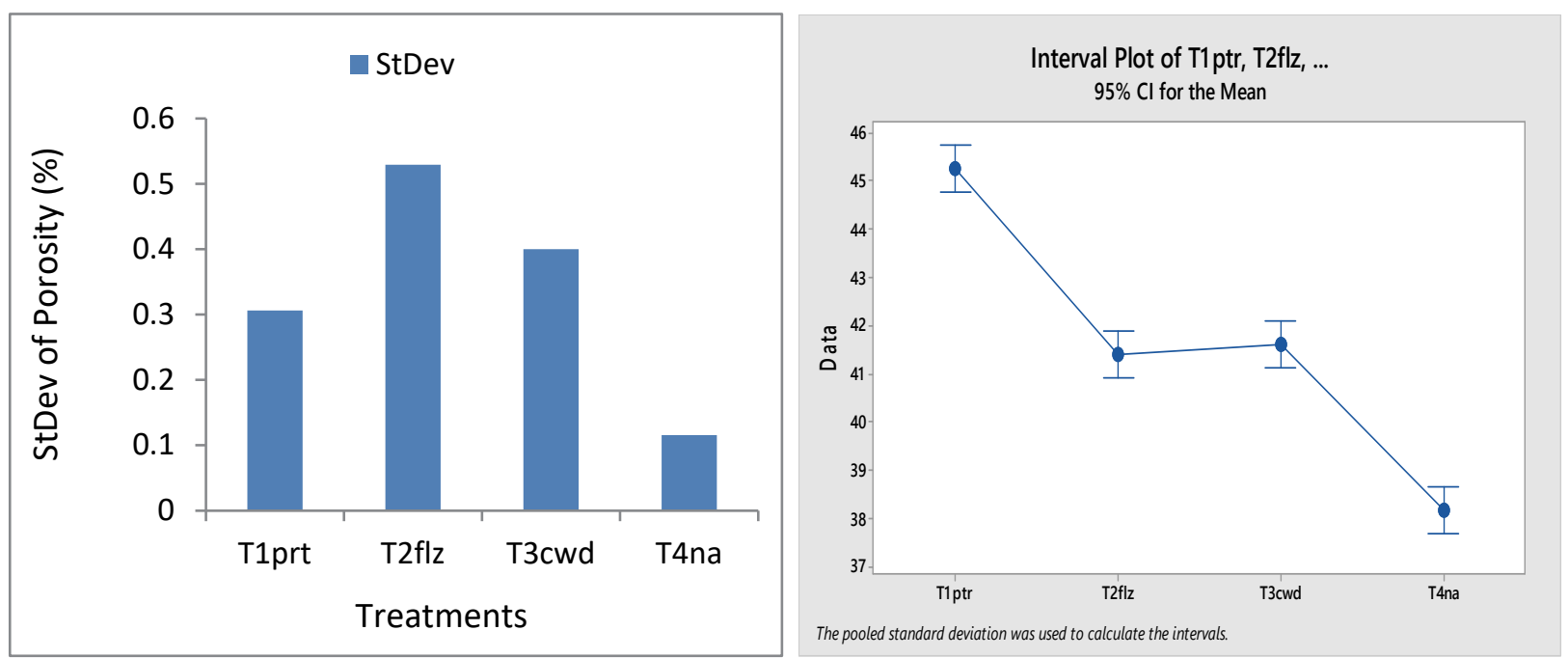

Figure 2.3. Standard Deviation bars of Porosity and interval plots as Affected by the treatments

From table 2.2 it shows that there is no significant difference between soil treated with poultry manure and that treated with NPK 15:15:15 as it relates to the porosity, but there was significant difference between soil treated with cow dung, soil with non-application and soil treated with poultry manure. Figure 2.3 (a) shows the standard deviation bars and interval plots of porosity as it is affected by the treatments. The soil treated with NPK 15:15:15 has the highest deviation with soil treated with poultry manure having the lowest deviation. The interval plots (b) also shows the significant differences between soils treated with poultry manure and that without application. The P-value of 0.00 shows that there is significant difference among the treatments.

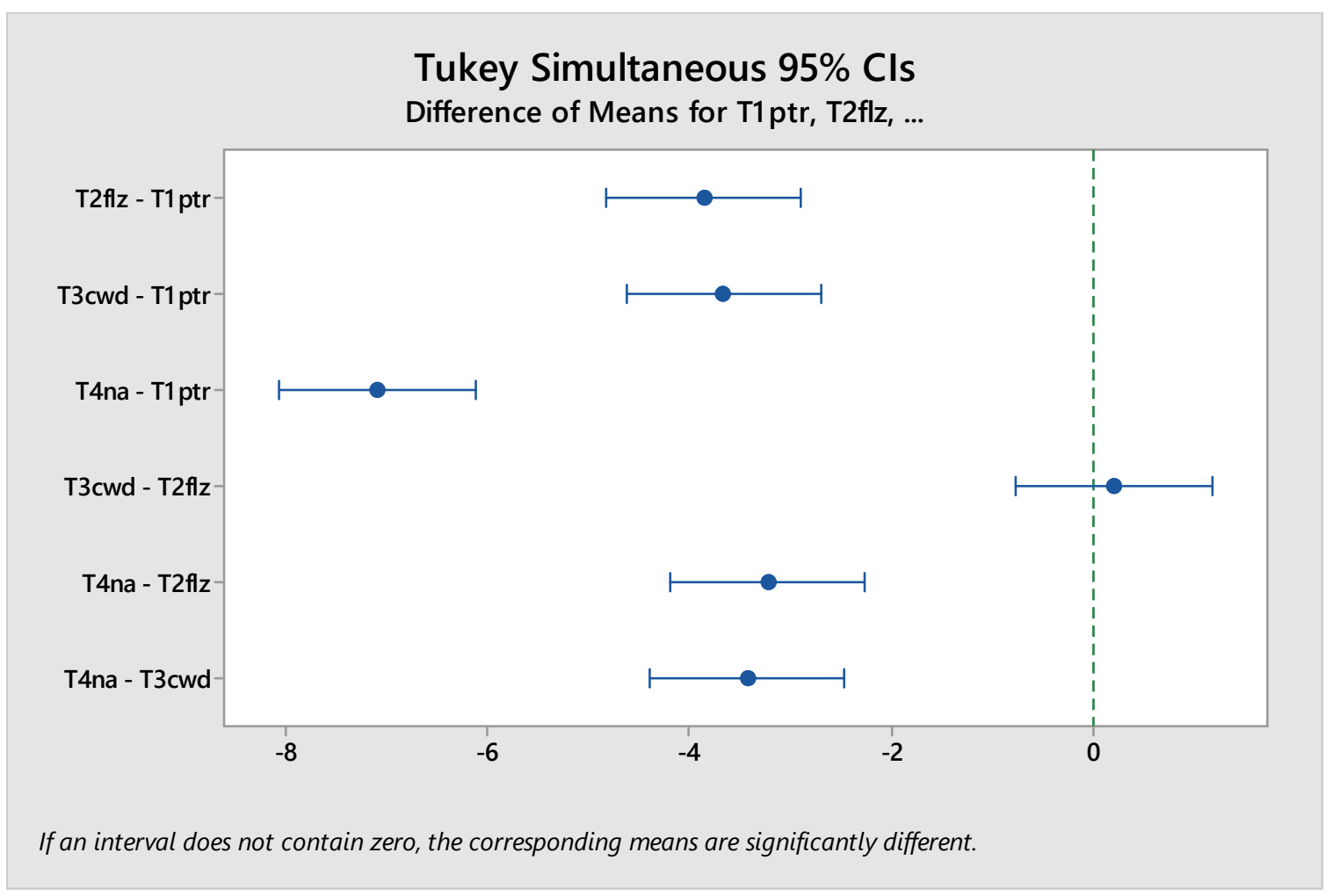

Figure 2.4. Confidence level of porosity plots 
Table 2.3. Particle, Bulk Densities and Porosity Relationships

\begin{tabular}{llll}
\hline Treatment & Particle Density & Bulk Density & Porosity \\
\hline Soil treated with poultry manure (T1ptr) & 2.65 & 1.46 & 0.45 \\
Soil treated with NPK (T2ftz) & 2.67 & 1.58 & 0.41 \\
Soil treated with cow dung manure(T3cwd) & 2.62 & 1.54 & 0.41 \\
No application (T4na) & 2.68 & 1.66 & 0.38 \\
\hline
\end{tabular}

\subsubsection{Soil Erodibility}

The Soil erodibility indicator, $\mathrm{K}$ for non-application was 0.056 that of soil treated with poultry manure was 0.0025 while the soil treated with cow dung was 0.575 and that of soil treated with NPK 15:15:15 was 0.063 .

Table 2.3. Erodibility Class

\begin{tabular}{lll}
\hline $\mathrm{S} / \mathrm{N}$ & Range (Value) & Class \\
\hline 1 & Less than 0.095 & Very low \\
2 & 0.095 to 0.113 & low \\
3 & 0.113 to 0.148 & Average \\
4 & 0.148 to 0.165 & high \\
5 & More than 0.165 & Very high \\
\hline
\end{tabular}

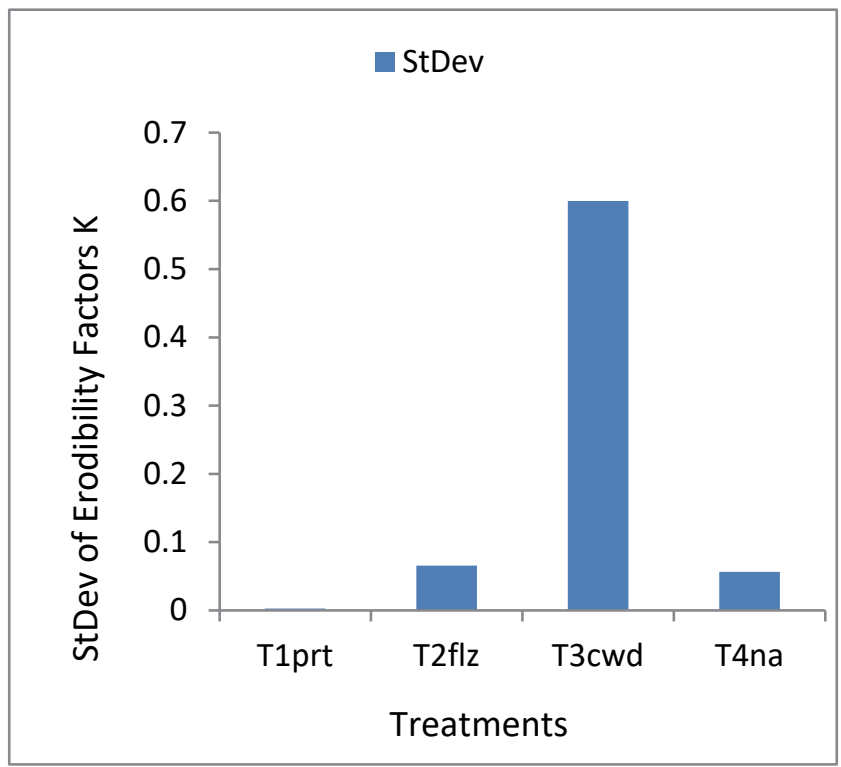

Figure 2.5. Standard Deviation (a) and confidence level (b) of Erodibility as affected by the Treatments

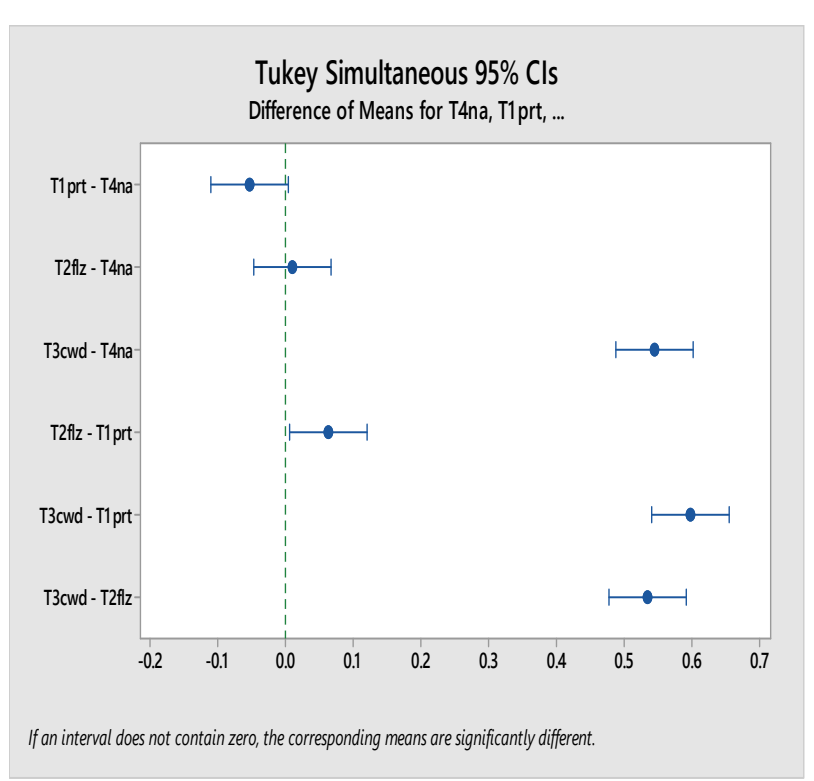

Table 2.2 shows the means of erodibilty factors $\mathrm{K}$, there is significant difference between soils treated with cow dung and all other treatments but there is no significant difference between soil treated with NPK 15:15:15 and non application but there is between the soil treatreted with NPK 15:15:15, non application and soil treated with poultry manure although there is no significant differnce between non application and soil treated with poulrty manure. Figure 2.5 shows standared devition bars and the confidence level plots. The soil treated with cowdung shows the highest devition with soil treated with poultry manrue shows lowest deviation. The bars that do not overlap show singificant deffrences for the chat dipicting confidence level (b). 


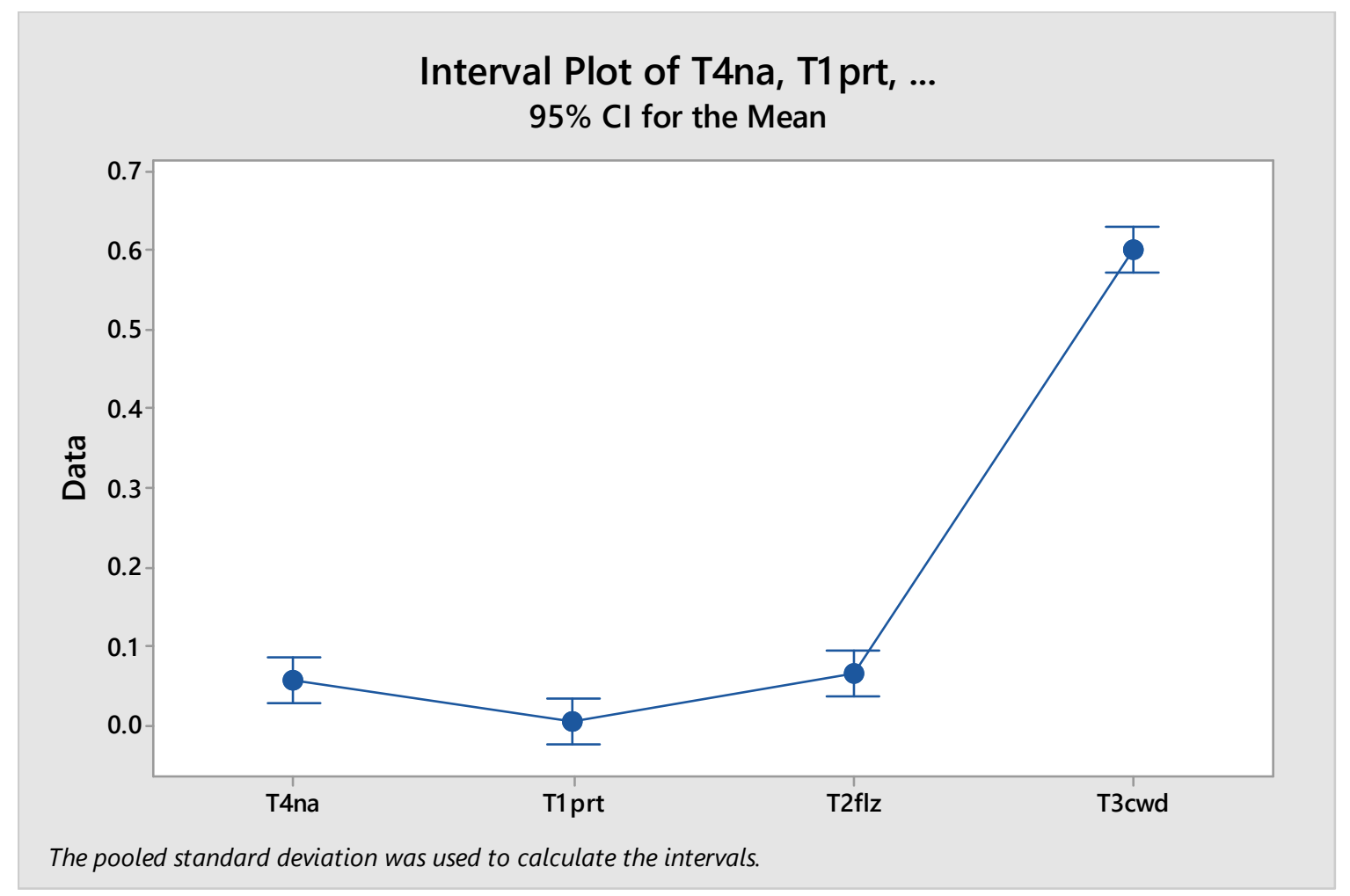

Figure 2.6. Interval Plots of Erodibility Factor K as Affected by the Soil Treatments

The P- value of 0.00 obtaind from the means shows that there is significant differences among the treatments. From figure 2.6, the soil treated with cow dung show high variation as compaerd with poultry with low variation among non application and NPK 15:15:15.

\subsubsection{Soil Infiltration Rates}

The infiltration capacity of soil is a very important factor for improving soil properties and maintenance against hazards.

Table 2.4. Means of Infiltration as Affected by Soil before and After Treatments

\begin{tabular}{|c|c|c|c|}
\hline Treatment & 25t/ha Poultry & $150 \mathrm{Kg} / \mathrm{ha}$ NPK & 25t/ha Cow Dung \\
\hline Infiltration $(\mathrm{cm} / \mathrm{hr})$ Before Treatment & $0.894 \mathrm{a}$ & $0.778 \mathrm{a}$ & $0.810 \mathrm{~b}$ \\
\hline Infiltration $(\mathrm{cm} / \mathrm{hr})$ After Treatment & $1.624 \mathrm{a}$ & $1.778 \mathrm{a}$ & $2.212 \mathrm{a}$ \\
\hline
\end{tabular}

Same letter within each column indicate no significant differences among the treatments $(\mathrm{P} \leq 0.05)$.

Table 2.5. Means of Infiltration as Affected by Soil Treatments

\begin{tabular}{lll}
\hline Treatment & Mean of Infiltration $\mathrm{cm} / \mathrm{hr}$ & StDev \\
\hline T1ptr 25t/ha & $1.6547 \mathrm{~b}$ & 0.0403 \\
T2npk $150 \mathrm{~kg} / \mathrm{ha}$ & $1.3400 \mathrm{~b}$ & 0.0027 \\
T3cwd 25t/ha & $2.2667 \mathrm{a}$ & 0.6430 \\
T4na & $0.6290 \mathrm{c}$ & 0.4580 \\
\hline
\end{tabular}

Same letter within each column indicate no significant differences among the treatments $(\mathrm{P} \leq 0.05)$. 
Table 2.4 shows the means of infiltration as affected by soil treatments. For soil treated with poultry manure and NPK 15:15:15 there was no significant difference between the means of before treatment and after treatment at $25 \mathrm{t} / \mathrm{ha}$, but there was significant defference between before and after apllication for soils treated with cow dung at $95 \%$ level of probability. Table 2.5 compared the means of the treatments. Soil treated with poultry manure and NPK 15:15:15 have no signifincant difference but are significantly different from soils treated with cow dung and non application. There is also signifincan differnce between soil treated with cow dung and non application at $95 \%$ level of probability. This shows that cow dung enhance more infiltration than all other treatments. This is also dipicted in the standared deviation values in table 2.5. The P-value of 0.003 obtained for soil
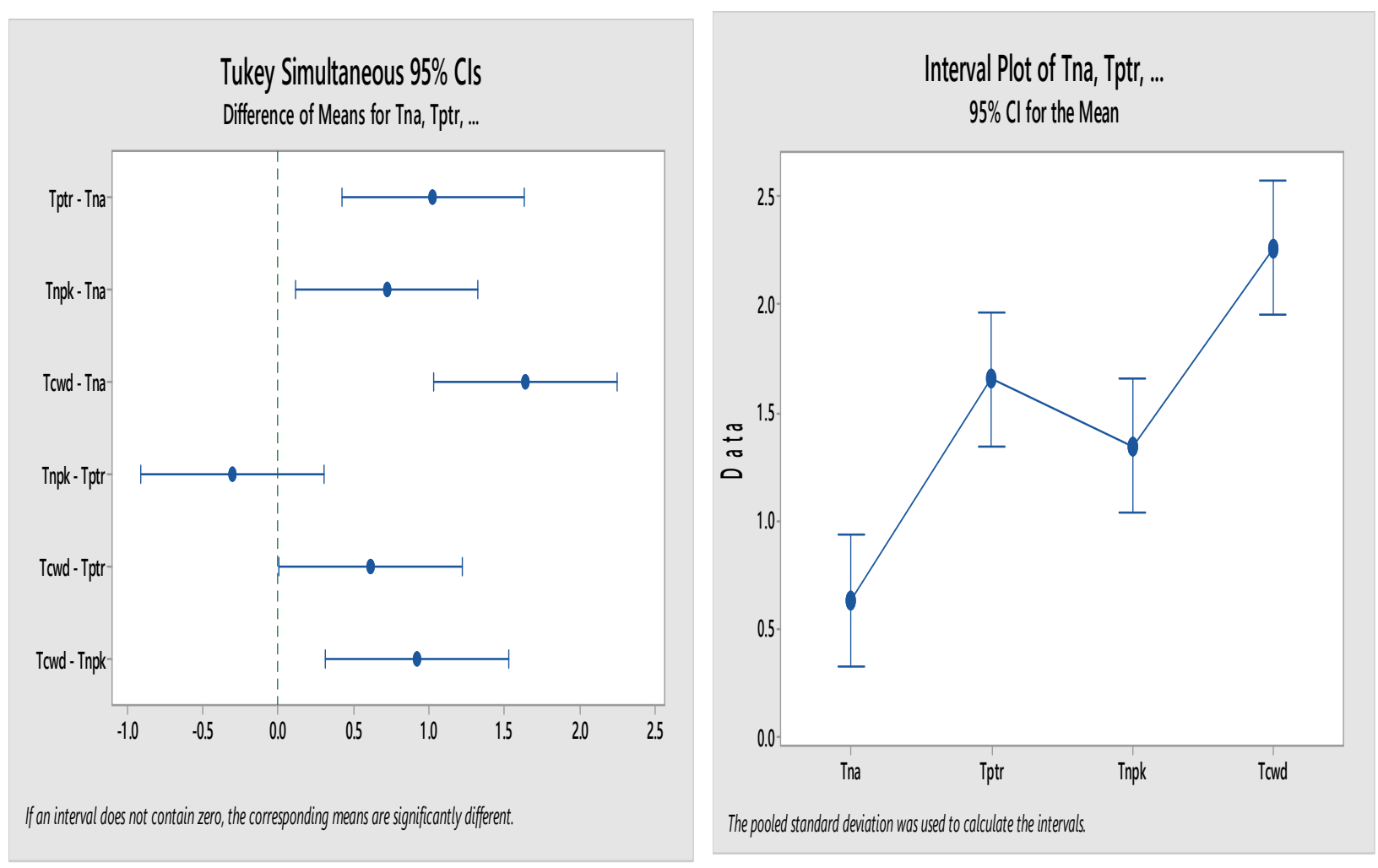

Figure 2.7. Confidence level (a) and Interval plots of Infiltration (b) as affected by the soil Treatments

Figure 2.7 shows the confidence level and Interval plots of Infiltration as affected by the soil Treatments. For the confidence level (a) if an interval does not contain zero, the corresponding means are significantly different. The interval plots show the upper and lower intervals. The P-value obtained for the soil treated with poultry and cow dung as 0.003 and 0.001 indicate significant differences between the treatments and 0.229 obtained for NPK shows that there is no significant difference between the treatments.

\section{Conclusion}

The study has shown that the use of poultry and cow dung manure at 25t/ha can amend and significantly improve soil physical properties suitable for agricultural purposes. They show significant influence on infiltration, porosity and bulk density of the soil. This improvement can reduce soil erosion thereby retaining soil fertility and structure. Organic matter incorporation to soil meant for agricultural purposes should be an integral management plan of tropical Alfisol to enhance infiltration rate, reduce bulk density and increase crop production.

\section{References}

Adepoju, A. Y. (1993). Evaluation of P-sorption capacity of forest and savanna soils of Nigeria. Tropical Agriculture(Trinidad), 70(2), 127-130.

Alberts, E. E., \& Wendt, R. C. (1985). Influence of soybean and corn cropping on soil aggregate size and stability. Soil Science Society of America Journal, $49,1537$. https://doi.org/10.2136/sssaj1985.03615995004900060040x

Alhassan, M., Mesaiyete, E., \& Mustapha, A. M. (2012). Clay mineralogy of Lateritic soils derived from granite basement. A case study of Minna lateritic soil. J. Geotech. Engineering, 17, 1897-1903. 
Anderson, S. H., Gantzer, C. J., \& Brown, J. R. (1990). Soil physical properties after 100 years of continuous cultivation. Journal of Soil and Water Conservation, 45, 117-121.

Angers, D. A., Mehuys, G.R. (1993). Aggregate stability to water In: Soil sampling and methods of analysis, Carter MR, Ed., Canadian Society of soil science. Lewis Publishers., ISBN 0-87371-861-5.

Bennett, J. G., Rains, A. B., Gosen, P, N., Howard, W. S., Hutchineon, A. A., Kerl, W. B., Mansfield, J. E., Rackhan, L. R., \& Innes, R. R. (1979). Land resources of central Nigeria. Agric. Dev. Possibilities. Vol. 58. The Kaduna Plains. LRD, Tolworth Tower, Survey, England. 130.

Carter, M. R. (1996). Analysis of Soil Organic Matter Storage in Agroecosystems. In Carter, M.R. \& Stewart, B. A., (eds): Structure and organic matter storage in agricultural soils, pp. 3-14. CRC Pres, Inc.

Cercioğlu, M., Okur, B., Delibacak, S., \& Ongun, A. R. (2014). Changes in physical conditions of a coarse textured soil by addition of organic wastes. Eurasian Journal of Soil Science, 3, 7-12. https://doi.org/10.18393/ejss.47968

Ekwue, E. I. (1990). Organic matter effects on soil strength properties. Soil Tillage Research, 16, $289-29$. https://doi.org/10.1016/0167-1987(90)90102-J

Evrendilek, F., Celik, I., \& Kilic, S. (2004). Changes in soil organic carbon and other physical properties along adjacent. Mediterranean forest, grassland, and cropland ecosystems in Turkey, 5(9), 743-752. https://doi.org/10.1016/j.jaridenv.2004.03.002

Fasinmirin, J. T., \& Adesigbin, A. J. (2012). Degree of compaction and compression strength of Nigeria Alfisol under tilled condition and different machinery traffic passes. International Journal of Agricultural \& Biological Engineering, 5(2), 34- 40. https://doi.org/10.9734/IJPSS/2014/5591

Fasinmirin, J. T., \& Olorunfemi, I. E. (2014). Soil erodibility estimation under different tillage systems assessment in the rain forest climate of Osun State, Nigeria. International Journal of Plant \& Soil Science, 3(1), 16- 35. Article no. IJPSS.2014.002.

Gajic, B., Dugalic, G., \& Djurovic, N. (2006). Comparison of soil organic matter content, aggregate composition and water stability of gleyic fluvisol from adjacent forest and cultivated areas. Agronomy Research, 4(2), 499-508.

Gantzer, C. J., Blake, G. R. (1978). Physical characteristics of Le Sueur clay loam soil following no-till and $\begin{array}{lllll}\text { conventional tillage. } & \text { Agronomy }\end{array}$ https://doi.org/10.2134/agronj1978.00021962007000050035x

Gantzer, C. J., Buyanovsky, G. A., Alberts, E. E., \& Remley, P. A. (1987). Effects of soybean and corn residue decomposition on soil strength and splash detachment. Soil Science Society of America Journal, 151, 202 207. https://doi.org/10.2136/sssaj1987.03615995005100010042x

Gregory, A.S., Kirk, G. J. D., Keay, C. A., Rawlins, B. G., \& Wallace, P., (2005). An assessment of subsoil organic carbon stocks in England and Wales.

Gülser, C., \& Candemir, F. (2006). Using pedotransfer functions to predict aggregation and permeability by hazelnut husk application. 18th International Soil Meeting (ISM) on "Soil Sustaining Life on Earth, Managing Soil and Technology" May, 22-26, Şanliurfa Turkey, Proceedings, Vol. (II), 847-852.

Gülser, C., \& Candemir, F. (2012). Changes in penetration resistance of a clay field with organic waste applications. Eurasian Journal of Soil Science, 1, 16-21.

Haynes, R. J. (2000). Interactions between soil organic matter status. cropping history, method of quantification and sample pretreatment and their effects on measured aggregate stability. Biology and Fertility of Soils, 30, 270-275. https://doi.org/10.1007/s003740050002

Hillel, D. (1982). Introduction to soil physics. Academic Press, San Diego, CA, USA. https://doi.org/10.1016/B978-0-08-091869-3.50005-6

Hunt, N., \& Gilkes, R. (1992). Farm Monitoring Handbook. The University of Western Australia: Nedlands, WA.

Jing, K., Wang, W. Z. and Zheng, F. L. (2005). Soil Erosion and Environment in China. Science Press, Beijing. 359.

Khormali, F., Ajami, M., Ayoudi, S., Srinivasarao, C. H., \& Wani, S. P. (2009). Role deforestation and hillslope position on soil quality attributes of loess-derived soils in Golestan province, Iran. Agriculture Ecosystems \& Environment, 134, 178-189. https://doi.org/10.1016/j.agee.2009.06.017 
Lal, R. (1991). Soil Erosion Research Methods. Science Press, Beijing. 236.

MacRae, R. J., \& Mehuys, G. R. (1985). The effect of green manuring on the physical properties of temperatearea soils. Advances Soil Science, 3, 71-94. https://doi.org/10.1007/978-1-4612-5090-6_2

McKenzie, N. J., Jacquier, D. J., Isbell, R. F., \& Brown, K. L. (2004). Australian Soils and Landscapes An Illustrated Compendium. CSIRO Publishing: Collingwood, Victoria. https://doi.org/10.1071/9780643100732

Morgan, R. P. (2001). A simple Approach to soil loss prediction. A revised Morgen-Finney model. Catena, 44(4), 305-322. https://doi.org/10.1016/S0341-8162(00)00171-5

Özdemir, N. (1993). Effects of admixturing organic residues on structure stability and erodibility of soils. Ataturk University. Journal of the Faculty of Agriculture, 24(1), 75-90.

Rogasik, J., Panten, K., Schnug, E., \& Rogasik, H. (2004). Infiltration Management Factors. Encyclopedia of Soil Science. https://doi.org/10.1201/NOE0849338304.ch178

Sparovek, G., M. M. Weill, S. B. L. Ranieri, Schnug, E., \& Silva, E. F. (2002). The life-time concept as a tool for erosion tolerance defini-Salviano, A.A.C., S.R. Vieira, and G. Sparovek. 1998. Erosion intensityandCrotalariajunceayield on a Southeast Brazilian ultisol.tion. Sci. Agric., 54, 130-135. https://doi.org/10.1590/S0103-90161997000300015

Tang, K. L. (2004). Soil and water conservation in China. Science Press, Beijing. 845 pp Wischmeier, W.H., Smith, D.D. (1978) Predicting rainfall erosion losses: a guide to conservation planning. USDA Handbook 537, Washington, DC.

Wang, B., Zheng, F., Römkens, M. J., \& Darboux, F. (2013). Soil erodibility for water erosion: A perspective and Chinese experiences. Geomorphology., 187, 1-10. https://doi.org/10.1016/j.geomorph.2013.01.018

Zheng, F. L., Yang, Q. K., \& Wang, Z. L. (2004). Water erosion prediction model. Research of Soil and Water Conservation, 11(4), 13-24.

\section{Copyrights}

Copyright for this article is retained by the author(s), with first publication rights granted to the journal.

This is an open-access article distributed under the terms and conditions of the Creative Commons Attribution license (http://creativecommons.org/licenses/by/4.0/). 